\title{
Coupling of dynamic hydrological response units and SWAT-MODFLOW to model the impact of vegetation change on hydrological processes in an arid endorheic river watershed
}

\section{Xin Jin}

Qinghai Normal University

Yanxiang Jin ( $\nabla_{\text {jinyx13@lzu.edu.cn ) }}$

Qinghai Normal University https://orcid.org/0000-0002-2140-5416

\section{Research Article}

Keywords: Revegetation, Irrigation, Leaf area index, Evapotranspiration, Groundwater

Posted Date: April 19th, 2021

DOI: https://doi.org/10.21203/rs.3.rs-270823/v1

License: (c) (i) This work is licensed under a Creative Commons Attribution 4.0 International License. Read Full License 


\section{Abstract}

Vegetation change in arid areas may lead to the redistribution of regional water resources, which can intensify the competition between ecosystems and humans for water resources. Thus, it is necessary to understand the impact of vegetation change on hydrological processes in arid areas. We aimed to accurately model the impact of vegetation change on hydrological processes in an arid endorheic river watershed undergoing revegetation. The middle and lower reaches of the Bayin River basin, China were investigated because this is an area of frequent surface water-groundwater interactions and evident revegetation. A LU-SWAT-MODFLOW model was developed by integrating dynamic hydrological response units with a coupled SWAT-MODFLOW model, which can reflect actual land cover changes in the basin. The results showed that the LU-SWAT-MODFLOW model outperformed the original SWAT-MODFLOW model in simulating human activity impact as well as the leaf area index, evapotranspiration, and groundwater table depth. After regional revegetation, evapotranspiration in different sub-basins increased by $1.5 \mathrm{~mm}$ per month and by $6 \mathrm{~mm}$ per year. The groundwater recharge increased by $1.27 \mathrm{~mm}$ on average per month and $14.02 \mathrm{~mm}$ on average per year. Irrigation for the recovered vegetation strongly affected the groundwater recharge. In addition, the direction and amount of surface water-groundwater exchange considerably changed in areas where revegetation involved converting low-coverage grassland and bare land to forestland. In areas where revegetation involved converting farmland to forestland, the transition had a weak effect on the direction and amount of surface water-groundwater exchange.

\section{Introduction}

Vegetation is essential for regional carbon sequestration, soil and water conservation, and climate regulation (Feng et al. 2016). Arid areas, which account for $40 \%$ of the world's land area, are characterised by water shortages and uneven spatiotemporal distributions of water resources. Changes in vegetation and related management practices (e.g. irrigation) in arid areas may lead to the redistribution of regional water resources, which can intensify the competition between ecosystems and humans for water resources (Reynolds et al. 2007; Feng et al. 2016). In this context, the water demand and water consumption characteristics of vegetation change in arid areas are of particular concern (Jackson et al. 2005; Menz et al. 2013).

Nowadays, physically based distributed (or semi-distributed) hydrological models can clearly reflect the spatial variability of hydrological processes in a basin, and these models are playing an important role in simulations and predictions of the hydrological cycle in basins (Quinn et al. 1991; Minacapilli et al. 2008; Xu et al. 2019). Notably, SWAT (Soil and Water Assessment Tools) is a typical distributed hydrological model with a strong physical foundation (J. G. Arnold et al. 2012). It is suitable for simulating surface hydrological processes in a complex basin with a variety of soil types, land use types, slopes, and management practices, and it can be used in data-poor regions (Panagopoulos et al. 2011; Nyeko 2015; Alemayehu et al. 2016). Currently, SWAT is a key component of the USDA-Conservation Effect Assessment Project and the USEPA-Hydrologic and Water Quality System (Yang and Zhang 2016). Nevertheless, SWAT has a weak ability to simulate groundwater processes, thereby limiting its application 
in arid areas with strong surface water-groundwater exchange (Kim et al. 2008; Bailey et al. 2016; Jin et al. 2018). Previous research has indicated that surface water and groundwater processes need to be simulated in a holistic manner to obtain an accurate picture of the water cycle processes, especially in arid areas (Kim et al. 2008).

The ability of SWAT to simulate groundwater processes can be improved through the following two approaches: (1) improving the groundwater process algorithms of SWAT (Sun et al. 2016; Jin et al. 2018), and (2) replacing the groundwater module of SWAT by a well-established groundwater model (Kim et al. 2008; Bailey et al. 2016). The groundwater process simulated by using the first approach is a lumped process on the scale of hydrological response units (HRUs), which is the basic calculation unit of SWAT, and therefore, increased errors in spatial simulations of groundwater flow fields are likely to occur (Reshmidevi and Nagesh Kumar 2014). The second approach allows the spatiotemporal characteristics of a basin to be described in a reasonable manner and the groundwater processes to be simulated more accurately, which ultimately improves the modelling accuracy of a basin's hydrological cycle (Kim et al. 2008; Bailey et al. 2016). A relatively well-established practice for the second approach is to couple SWAT with a MODFLOW model by using the same temporal and spatial scales for both models, thereby allowing SWAT to calculate and input HRU-based groundwater recharge data to the MODFLOW model, and then, allowing the MODFLOW model to calculate and return the groundwater flow between the aquifer and river to SWAT (Kim et al. 2008; Bailey et al. 2016). The SWAT-MODFLOW code developed by Bailey et al. (2016) couples the most recent SWAT code with the MODFLOW-NWT code, which improves the solution of unconfined groundwater flow problems (Liu et al. 2019). This version of a coupled SWATMODFLOW model has been successfully applied in numerous countries and regions (Reshmidevi and Nagesh Kumar 2014; Liu et al. 2019).

Nowadays, SWAT-MODFLOW is more suitable for expressing the natural water cycle of 'atmosphereslope-underground-river' components. In this process, the impact of human activities, such as land use/land cover change, is generalised (Jin et al. 2018). However, in view of increasingly intense human activities, full consideration of both the impact of human activities and natural factors on the water cycle process in a basin is paramount to ensuring that distributed hydrological models can accurately describe the water cycle process (Zhang et al. 2013; Wang et al. 2018). Intensive vegetation change is one of the final results of human activities (Reynolds et al. 2007). Vegetation growth in SWAT is a key process to consider in the quantitative modelling of eco-hydrological processes, as it directly affects evapotranspiration (ET), water interception, and soil erosion (Wang et al. 2018). Therefore, accurate determination of vegetation change in different HRUs is key to modelling hydrological processes (Ma et al. 2019a). SWAT can reflect vegetation changes in a basin by using a land use update module (Wang et al. 2018). However, HRUs, the basic computational units of SWAT, are virtual units, each of which is treated as a lumped unit to achieve the same soil type, land use/cover type, and slope at different spatial sites. This makes it infeasible for SWAT to effectively reflect partial land cover type conversions or land cover type convert to multiple other landcovers within the same HRU. To overcome this limitation of the HRUs, it is essential to model the impact of vegetation change on hydrological processes. 
The Qaidam Basin, which is situated in the north-eastern part of the Tibetan Plateau, is in a cold and arid climate, and it has one of the harshest and most fragile ecological environments worldwide. Although the basin is situated deep in the hinterland, it contains many inland river systems, which form many oases suitable for human survival. The rivers, which are formed in the upper mountainous areas, run through the middle and lower plains and eventually enter the terminal lake, thereby forming a closed water cycle system through the upper, middle, and lower reaches (Shen et al. 2015). The Bayin River, which is situated in the northeast part of the Qaidam Basin, is the fourth largest inland river in the region. Since 2002, revegetation measures such as the 'Grain-for-Green' program have been implemented in the Bayin River basin, and these efforts have led to significant increases in the forestland and grassland with corresponding high rates of water consumption. These revegetation and irrigation measures have produced significant impacts on the regional subsurface and water cycle.

Given the above context, this study aimed to develop a LU-SWAT-MODFLOW model by integrating a coupled SWAT-MODFLOW model with dynamic HRUs, which can overcome the limitation of considering the vegetation change compared to the original HRUs for the middle and lower reaches of the Bayin River basin, where there are frequent surface water-groundwater interactions and evident vegetation change. With the advancement of remote sensing technology, data products with high spatiotemporal resolution such as leaf area index (LAl) and ET combined with observed hydrological data were used to calibrate the model (Ma et al. 2019; Jin and Jin 2020). This study can provide support for ensuring revegetation sustainability and help in rationally allocating water resources in arid areas.

\section{Materials And Methods}

\subsection{Study area}

The Bayin River, which is the fourth largest river in the Qaidam Basin, is situated at the north-eastern edge of the basin on the Tibetan Plateau (Fig. 1). The basin is in an arid area with desert and semi-desert lands and has a plateau climate with high winds, sand storms, and little rain; barren lands are present here. The Bayin River flows out of the mountains into the middle and lower reaches where human population and industrial and agricultural activities are concentrated, and there is frequent surface water-groundwater exchange here. The vegetation in the Bayin River basin has been restored substantially with the implementation of a series of ecological restoration measures such as the Grain-for-Green program over the past 20 years. However, irrigation has become essential for such artificial revegetation projects because of the arid climate and the heterogeneity in the spatial distribution of water resources.

\subsection{SWAT-MODFLOW model}

In this study, the coupling of SWAT with the MODFLOW model was achieved by using the method of Bailey et al. (2016). Given the inconsistency between the two models in terms of computational spatial units, it was necessary to use a GIS platform to unify the spatial resolution of the two models before model coupling (Fig. 2). First, specific spatial locations were allocated to the computational units (HRUs) of SWAT. Second, a mapping relationship was established between the HRUs of SWAT and the 
computational grid cells of MODFLOW on the same projected coordinate system using a GIS platform (Kim et al. 2008; Bailey et al. 2016). Third, the SWAT model was run to simulate the groundwater recharge, evaporation, and extraction with a temporal step of $1 \mathrm{~d}$. Finally, the simulation results were taken as boundary conditions on the corresponding computational grid cells of MODFLOW for groundwater flow modelling (Bailey et al. 2016). The MODFLOW model was run to simulate the groundwater processes while using the groundwater monitoring data of the basin to calibrate and validate the model parameters. Meanwhile, the simulated groundwater table depth from the MODFLOW model was transferred to the computational units of surface water through the abovementioned mapping relationship to impose boundary conditions on the simulation of irrigation groundwater extraction, crop growth, and vegetation transpiration, as well as to test the simulation results (Bailey et al. 2016). Taken together, the above steps led to accurate descriptions of the water cycle processes in the basin.

\subsection{SWAT-MODFLOW model Coupled with dynamic HRUs}

In view of the inability of the original SWAT model to effectively reflect complete or partial land cover type conversions within the same HRU, this study transformed the HRUs of the original SWAT model to dynamic HRUs to improve on the original model. The generation process of dynamic HRUs is illustrated in Fig. 3. In contrast to the original HRUs, the generation process of dynamic HRUs involved the defining of spatial units where there were land use/cover changes, i.e. it incorporated the concept of dynamic land use/cover. Such spatial units were combined with soil type and slope data to generate dynamic HRUs that each had a specific and invariant location, area, and shape with variable attributes. Such dynamic HRUs can more truly reflect the land use/cover changes in the basin.

The operational flow chart of the coupled SWAT-MODFLOW model based on dynamic HRUs is shown in Fig. 4. First, annual cycle simulations were performed by using corresponding HRUs (land cover). Second, daily cycle simulations were performed, in which hydrological processes were simulated by SWAT. The simulation results on each HRU were mapped to the computational grid cells of MODFLOW, where these were taken as boundary conditions for groundwater flow simulations. Third, the simulated groundwater data within the grid cells were mapped to the HRUs of SWAT for subsequent SWAT computations. The above process was conducted in nested loops until the end of the simulated time period. Considering that the dynamic HRU-based SWAT-MODFLOW coupled model could reflect the dynamic changes in land use/cover, the model was referred to as LU-SWAT-MODFLOW.

\subsection{Model establishment}

Meteorological data required for establishing the SWAT model included the daily monitoring data for precipitation, temperature, relative humidity, wind speed, and solar radiation at the Delingha weather station, which is located at the inlet shown in Fig. 1. Agricultural, forestland, and grassland irrigation data were obtained from the Delingha Municipal Water Affairs Bureau (Table 1). Digital elevation model data (Fig. 1) of 30-m-resolution Shuttle Radar Topography Mission data (http://gdex.cr.usgs.gov/gdex/) were used. Soil type data (Fig. 5a) at the scale 1:1,000,000 from China were used (https://data.tpdc.ac.cn/), and the corresponding soil hydrological attributes were retrieved from the Qinghai Soil Record. Figure $5 \mathrm{~b}$ presents the sub-basin division map of the study region. 
Table 1

Irrigation volume in the study region.

\begin{tabular}{|c|c|c|c|}
\hline Irrigation type & $\begin{array}{l}\text { Annual irrigation rate } \\
\left(\mathrm{m}^{3} / \mathrm{hm}^{2}\right)\end{array}$ & Number of times of irrigation & Irrigation duration \\
\hline Agricultural irrigation & 5800 & 6 & March-October \\
\hline Forest irrigation & 5400 & 6 & April-November \\
\hline Grassland irrigation & 3600 & 5 & April-November \\
\hline
\end{tabular}

Land use type data for the simulated period (2000-2018) were derived from the interpretation of 30-m Landsat images. Remote sensing interpretation marks were created according to spectral features combined with field survey data and relevant geographic maps. Data quality was examined by comparatively analysing field survey patches versus randomly selected patches, and the classification accuracy was determined to be over $90 \%$. Figure 6 presents the regional spatial distribution of land use/cover in 2000 (Fig. 6a) versus 2018 (Fig. 6b). There were six types of land use/cover in 2000, namely, spring wheat, forest, grassland, water, residences, and barren land. There were seven types in 2018, including 'Chinese wolfberry' as a new type in addition to the existing six types. In the study region, Chinese wolfberry was the main tree species used for artificial revegetation. Considering the absence of Chinese wolfberry-related parameters in the built-in land use and vegetation database of SWAT, relevant parameters for apple trees in the SWAT model were taken as default parameters for Chinese wolfberry, and these were calibrated by using the LAl data to simulate the growth process of Chinese wolfberry. Other relevant parameters of land use/cover types were either set to the default values in the built-in database of the model or obtained by calibration. Revegetation in the study region was mainly characterised by the conversion of farmland to forestland and the conversion of bare land to forestland and grassland. From 2000 to 2018, the years when evident vegetation changes (restoration) occurred in the study region were $2005,2008,2015$, and 2018. Accordingly, the land use data for $2000,2005,2008$, 2015, and 2018 were used to generate dynamic HRUs. In contrast, land cover types in the other years were only weakly altered and therefore ignored.

Basin boundaries delineated by the SWAT model were considered as impermeable boundaries to groundwater flow in the MODFLOW model, where the western and eastern outlets of the basin were considered as constant flow boundaries. The river network extracted by the SWAT model was considered to constitute river boundaries in the MODFLOW model. The simulated steady-state heads (Fig. 7) were used as the initial heads for simulations of transient flow. In addition, the shallow aquifers in the study region were conceptualised as being non-homogeneous and anisotropic according to relevant studies, and the groundwater flow was conceptualised as a two-dimensional transient flow.

\subsection{Model calibration data and method}


The period 2000-2001 was used as the model warm-up period, and 2002-2018 was used as the model calibration period. Vegetation growth parameters in the SWAT model were calibrated at HRU scales against the monthly $30 \mathrm{~m}$ resolution LAI data of 2002-2018 provided by the National Tibetan Plateau/Third Pole Environment Data Centre (http://data.tpdc.ac.cn/). ET simulated by the LU-SWATMODFLOW model was calibrated at sub-basin scales against the TDPC-provided ET data at a $0.1^{\circ} \times 0.1^{\circ}$ resolution (Fig. 8). Relevant parameters of the MODFLOW model were calibrated against monthly recorded groundwater table depth at numerous observation wells (Fig. $5 b$ ) in the basin.

In the present study, land cover types varied over the years within some dynamic HRUs or remained invariant throughout the whole simulated period or over a relatively long period within some of the HRUs. The HRUs in the latter scenario were chosen to calibrate the relevant vegetation growth parameters (Table 2) against monthly 30-m-resolution LAl data (Ma et al. 2019). The calibrated parameters were stored in a separate file, which could be visited during SWAT operations to directly tune parameters in HRUs where changes in land cover type were detected. Parameter calibration at sub-basin scales in the present study was mainly based on remote sensing-derived ET data in accordance with the method of White and Chaubey (2005).

Table 2

Vegetation growth-related parameters in SWAT.

\section{Parameter Description}

BLAl Maximum potential leaf area index

LAIMX_1 Fraction of the maximum leaf area index corresponding to the 1st point on the optimal leaf area development curve

FRGRW1 Fraction of the plant growing season corresponding to the 1st point on the optimal leaf area development curve

LAIMX_2 Fraction of the maximum leaf area index corresponding to the 2nd point on the optimal leaf area development curve

FRGRW2 Fraction of the plant growing season corresponding to the 2nd point on the optimal leaf area development curve

DLAl Fraction of growing season when leaf area begins to decline

BIO_E Radiation use efficiency

EXT_COEF Light extinction coefficient

GSI Maximum canopy stomatal conductance

HVSTI Harvest index for the optimal growing condition

T-BASE Minimum (base) temperature for plant growth 


\subsection{Model performance metrics}

The applicability of SWAT was evaluated in terms of Nash-Sutcliffe Efficiency (NSE), percent bias (PBIAS), root mean square error (RMSE), and squared correlation coefficient $\left(\mathrm{R}^{2}\right)$. The NSE can range between $-\infty$ to 1 . If the value of the NSE was closer to 1 , then this was indicative of a better simulation performance and high reliability of the SWAT model. When the NSE was closer to 0.5 , the model simulation results were similar to the mean of observations, that is, the model results in general were reliable. A PBIAS between $-10 \%$ and $10 \%$ indicated a good simulation performance of the model. Additionally, larger values of $\mathrm{R}^{2}$ were indicative of a better simulation performance of the model. The calculation process and significance of the three metrics have been elaborated elsewhere (Moriasi et al. 2007). Model performance during the simulations of the groundwater table depth was evaluated mainly in terms of the absolute error and $\mathrm{R}^{2}$ in this study.

\section{Results And Discussion}

\subsection{Regional vegetation change}

The main types of vegetation change in the study region from 2002 to 2018 are summarised in Table 3 . Specifically, the main types of vegetation change pertained to the conversion of low-coverage grassland, farmland, and bare land to forestland, in which the converted areas amounted to 2,877, 518, and 321 $\mathrm{hm}^{2}$, respectively. Correspondingly, the irrigation water volume of each revegetation plot underwent dramatic changes. In addition, the conversion of farmland to forestland mainly occurred in the Gahai Lake-irrigated area in the south-eastern part of the basin, while the conversion of low-coverage grassland and bare land to forestland mainly occurred in the irrigated area of Delingha, which is situated in the north-western part of the basin (Fig. 6).

Table 3

Main types of revegetation in the study region.

\begin{tabular}{|lll|}
\hline Main type of revegetation & $\begin{array}{l}\text { Revegetation area } \\
\left(\mathrm{hm}^{2}\right)\end{array}$ & $\begin{array}{l}\text { Change in the annual irrigation rate } \\
\left(\mathrm{m}^{3} / \mathrm{hm}^{2} \cdot \mathrm{a}\right)\end{array}$ \\
\hline $\begin{array}{l}\text { Conversion of low-coverage grassland } \\
\text { to forestland }\end{array}$ & 2877 & $0 \rightarrow 5400$ \\
\hline $\begin{array}{l}\text { Conversion of farmland to forestland } \\
\text { Conversion of bare land to forestland }\end{array}$ & 518 & $5800 \rightarrow 5400$ \\
\hline
\end{tabular}

\subsection{Comparison of the original SWAT-MODFLOW and LU-SWAT-MODFLOW}

\subsubsection{Difference in HRUs}


Figure 9 shows the HRUs generated by the original SWAT-MODFLOW model versus those from the LUSWAT-MODFLOW model. The original SWAT-MODFLOW model generated 1,304 HRUs, and the LU-SWATMODFLOW model generated 2,978 HRUs. The higher number of HRUs in the new model was due to the land use/cover data of LU-SWAT-MODFLOW being a superposition of years-long data and thereby covering a higher number of patches. The higher number of HRUs also implied that the operation and parameter tuning of the LU-SWAT-MODFLOW model would be more complicated (Jin et al. 2015).

\subsubsection{Comparison of the LAl simulation results}

Model calibration made the simulation results reliable. Figure 10 shows the simulated LAI from the calibrated original SWAT-MODFLOW model versus the calibrated LU-SWAT-MODFLOW model for July $2005,2010,2015$, and 2018. The performance metrics for the calibrated original SWAT-MODFLOW model were NSE $>0.82$, PBIAS of $-20-20 \%$, and $\mathrm{R}^{2}>0.81$ in simulations of the monthly LAI on each of the 10 randomly chosen HRUs, and the counterparts for the calibrated LU-SWAT-MODFLOW were NSE $>0.88$, PBIAS of $-20-20 \%$, and $\mathrm{R}^{2}>0.87$ (Table 4). This indicates that the LU-SWAT-MODFLOW model was more accurate than the original SWAT-MODFLOW model in simulations of the monthly LAI after both models were calibrated.

Table 4

Performance of the calibrated original SWAT-MODFLOW model versus the calibrated LU-SWAT-MODFLOW model in simulating LAI.

\begin{tabular}{|lllllll|}
\hline \multicolumn{3}{|c}{ SWAT-MODFLOW } & \multicolumn{4}{c|}{ LU-SWAT-MODFLOW } \\
\hline HRU & NSE & PBIAS (\%) & $\mathrm{R}^{2}$ & NSE & PBIAS $(\%)$ & $\mathrm{R}^{2}$ \\
\hline E1 & 0.85 & 20.84 & 0.83 & 0.92 & 14.11 & 0.88 \\
E2 & 0.86 & 23.71 & 0.85 & 0.91 & 11.13 & 0.87 \\
\hline W1 & 0.82 & 19.89 & 0.82 & 0.88 & 13.45 & 0.90 \\
\hline W2 & 0.83 & 17.41 & 0.81 & 0.89 & 12.65 & 0.89 \\
S1 & 0.85 & 13.72 & 0.84 & 0.90 & 10.99 & 0.90 \\
\hline S2 & 0.83 & 19.24 & 0.81 & 0.91 & 11.11 & 0.90 \\
\hline N1 & 0.87 & 15.36 & 0.85 & 0.93 & 14.65 & 0.92 \\
\hline N2 & 0.86 & 17.52 & 0.84 & 0.90 & 17.53 & 0.89 \\
\hline C1 & 0.84 & 21.49 & 0.83 & 0.92 & 16.46 & 0.90 \\
\hline C2 & 0.85 & 20.76 & 0.83 & 0.91 & 13.02 & 0.92 \\
\hline
\end{tabular}

\subsubsection{Comparison of the ET simulation results}


Model calibration was performed on 10 ET-sensitive parameters (Table 5) identified by a parameter sensitivity analysis.

Table 5

Evapotranspiration-sensitive parameters of SWAT.

\begin{tabular}{|ll|}
\hline Parameter & Description \\
\hline SOL_K & Saturated soil permeability coefficient \\
\hline SOL_AWC & Effective water content of soil layer \\
\hline SLSUBBSN & Average slope length \\
\hline ESCO & Soil evaporation compensation factor \\
\hline CN2 & Initial SCS runoff curve number for moisture condition II \\
\hline CANMX & Maximum canopy storage \\
\hline SMFMN & Melt factor for snow on December 21 \\
\hline CH_N2 & Manning coefficient of the main channel \\
\hline SNOCOVMX & Minimum snow water content that corresponds to $100 \%$ snow cover \\
\hline ALPHA_BF & Baseflow alpha factor \\
\hline
\end{tabular}

Figure 11 shows the multi-year mean of the simulated ET from the calibrated original SWAT-MODFLOW model (Fig. 11a) versus that of the calibrated LU-SWAT-MODFLOW model (Fig. 11b) in comparison with the multi-year mean of remote sensing-derived ET (Fig. 11c). The multi-year mean of remote sensingderived ET exhibited a spatial distribution pattern of high values in the north-eastern mountains and low values in the southwestern plains, while such a distribution pattern was absent for both calibrated models. This discrepancy likely occurred because the remote sensing-based calculation of ET did not consider the impacts of agricultural, forestland, and grassland irrigation (Ma et al. 2019). In contrast, the multi-year mean of simulated ET from both calibrated models was distributed in agricultural and revegetation areas where high amounts of water had been used for irrigation. In particular, the high-mean areas in the case of the calibrated LU-SWAT-MODFLOW model were more widespread than those of the calibrated original SWAT-MODFLOW model, and this was because the revegetation and related irrigation were considered in the former case. The performance metrics of the calibrated original SWAT-MODFLOW model were NSE $>0.65$, PBIAS of $-20-20 \%$, and $\mathrm{R}^{2}>0.63$ in simulations of the monthly mean ET for each sub-basin, while the counterparts for the calibrated LU-SWAT-MODFLOW model were NSE $>0.72$, PBIAS of $-20-20 \%$, and $\mathrm{R}^{2}>0.75$ (Table 6). This indicates that when both models were calibrated, the LU-SWAT-MODFLOW model was more accurate than the original SWAT-MODFLOW in simulations of the monthly mean ET for most of the sub-basins. 
Table 6

Performance of the calibrated original SWAT-MODFLOW model versus the calibrated LU-SWAT-MODFLOW model in simulating evapotranspiration.

\begin{tabular}{|c|c|c|c|c|c|c|}
\hline \multirow[b]{2}{*}{ Sub-basins } & \multicolumn{3}{|c|}{ SWAT-MODFLOW } & \multicolumn{3}{|c|}{ LU-SWAT-MODFLOW } \\
\hline & NSE & PBIAS & $\mathrm{R}^{2}$ & NSE & PBIAS & $R^{2}$ \\
\hline 1 & 0.70 & 15.60 & 0.73 & 0.73 & 13.90 & 0.75 \\
\hline 2 & 0.72 & 14.80 & 0.70 & 0.78 & 16.10 & 0.81 \\
\hline 3 & 0.75 & 17.60 & 0.77 & 0.75 & 16.80 & 0.78 \\
\hline 4 & 0.77 & -13.30 & 0.74 & 0.75 & -17.30 & 0.83 \\
\hline 5 & 0.71 & 14.30 & 0.70 & 0.84 & 11.40 & 0.86 \\
\hline 6 & 0.71 & 11.70 & 0.68 & 0.72 & 18.00 & 0.76 \\
\hline 7 & 0.68 & 12.60 & 0.70 & 0.72 & 19.20 & 0.77 \\
\hline 8 & 0.75 & 15.70 & 0.71 & 0.87 & 5.20 & 0.87 \\
\hline 9 & 0.65 & -10.10 & 0.63 & 0.86 & -14.40 & 0.88 \\
\hline 10 & 0.71 & 10.30 & 0.70 & 0.85 & 6.40 & 0.86 \\
\hline 11 & 0.69 & 10.60 & 0.65 & 0.88 & -0.70 & 0.88 \\
\hline 12 & 0.67 & -14.40 & 0.70 & 0.83 & -18.90 & 0.88 \\
\hline 13 & 0.71 & -8.90 & 0.68 & 0.87 & -11.20 & 0.89 \\
\hline 14 & 0.71 & -8.60 & 0.67 & 0.86 & -11.10 & 0.88 \\
\hline 15 & 0.67 & 15.30 & 0.65 & 0.79 & 16.50 & 0.82 \\
\hline 16 & 0.66 & 17.20 & 0.68 & 0.84 & 10.50 & 0.86 \\
\hline 17 & 0.70 & 10.80 & 0.70 & 0.79 & 16.10 & 0.82 \\
\hline 18 & 0.71 & 10.10 & 0.72 & 0.84 & 7.30 & 0.85 \\
\hline 19 & 0.76 & -3.30 & 0.75 & 0.75 & -9.20 & 0.80 \\
\hline 20 & 0.76 & -4.20 & 0.74 & 0.76 & -9.20 & 0.80 \\
\hline 21 & 0.71 & 17.60 & 0.68 & 0.83 & 8.40 & 0.84 \\
\hline 22 & 0.77 & 14.20 & 0.66 & 0.78 & 19.50 & 0.83 \\
\hline 23 & 0.76 & 12.20 & 0.72 & 0.73 & 14.90 & 0.82 \\
\hline 24 & 0.78 & 10.70 & 0.71 & 0.83 & 0.60 & 0.83 \\
\hline
\end{tabular}




\begin{tabular}{|lllllll|}
\hline & \multicolumn{3}{l}{ SWAT-MODFLOW } & \multicolumn{3}{c|}{ LU-SWAT-MODFLOW } \\
\hline 25 & 0.76 & 10.70 & 0.69 & 0.86 & 5.60 & 0.87 \\
\hline 26 & 0.68 & 13.10 & 0.73 & 0.86 & -5.40 & 0.86 \\
\hline 27 & 0.77 & 13.30 & 0.74 & 0.84 & 7.60 & 0.85 \\
\hline 28 & 0.78 & 10.80 & 0.76 & 0.83 & 12.50 & 0.85 \\
\hline 29 & 0.78 & -8.80 & 0.74 & 0.77 & -19.60 & 0.91 \\
30 & 0.67 & 12.50 & 0.68 & 0.86 & -0.80 & 0.86 \\
\hline 31 & 0.72 & 0.70 & 0.70 & 0.85 & 4.10 & 0.85 \\
\hline 32 & 0.74 & 1.20 & 0.72 & 0.87 & 3.30 & 0.87 \\
\hline 33 & 0.76 & -11.70 & 0.75 & 0.86 & -18.90 & 0.90 \\
\hline
\end{tabular}

\subsubsection{Comparison of the simulation results for groundwater table depth}

Groundwater table depth data were scarce within the study region. Observation well 1 only provided monthly data for 2009-2011, and observation wells 2, 3, and 4 only provided monthly data for 20132015; meanwhile, observation well 5 only provided monthly data for 2014-2015. Linear regression results of the simulated groundwater table depth on observed groundwater table depth were compared between the original SWAT-MODFLOW model and the LU-SWAT-MODFLOW model (Fig. 12). Both models performed well in simulating the changes in the groundwater table depth of the study region, with an $\mathrm{R}^{2}>$ 0.95 and absolute error within $0.5 \mathrm{~m}$. In addition, the simulation performance of LU-SWAT-MODFLOW was slightly better than that of SWAT-MODFLOW, which was likely attributed to the detailed consideration of the spatiotemporal changes in irrigation and land cover by the former model versus the latter model.

\subsection{Impacts of vegetation change on hydrological processes}

\subsubsection{Impacts on ET}

The LU-SWAT-MODFLOW model was run in the following two scenarios to accurately analyse the impacts of revegetation and the related extensive irrigation on ET: (1) revegetation was assumed absent while considering the actual changes in other types of land use/cover; (2) the actual changes in land use/cover were considered, including those pertinent to revegetation (irrigation) and other types of land use/cover. Figure 13a shows the simulated monthly ET in the revegetation-absent scenario versus the revegetationpresent scenario from 2002 to 2018. The results indicated that revegetation and related irrigation did not change the trend of monthly ET in the basin, in which the monthly ET in the revegetation-present scenario was only $1.5 \mathrm{~mm}$ higher than that in the revegetation-absent scenario for most months. Similarly, the trend of annual ET was almost the same in both scenarios. In 2004 and beyond, ET showed significantly higher values in the revegetation-present scenario than in the revegetation-absent scenario (Fig. 13b). 
Figure 13c illustrates the difference in the multi-year mean annual ET between the two scenarios in each sub-basin. Such a difference was greater than $10 \mathrm{~mm}$ in sub-basins 4, 12,13, 14, 26, and 33, that is, the ET increase was most obvious in these sub-basins. Comprehensive comparisons of the land use/cover map (Fig. 6) with the LAI map for the study region during the study period further confirmed that relatively obvious revegetation had been achieved in these sub-basins.

\subsubsection{Impacts on groundwater recharge}

Groundwater is the most important water resource in the arid endorheic river watershed. Changes in groundwater recharge may affect the groundwater storage and further impact the ecological environment. Figure 14 shows the monthly (Fig. 14a) and yearly (Fig. 14b) groundwater recharge in the entire study area. After revegetation, the groundwater recharge increased by about $1.27 \mathrm{~mm}$ on average per month and $14.02 \mathrm{~mm}$ on average per year. The groundwater recharge with revegetation was evidently higher than that without revegetation in irrigation seasons. Moreover, in Fig. 14c, we calculated the yearly average groundwater recharge after revegetation in the entire study area. The groundwater recharge in the irrigation district where the revegetation applied was the highest $\left(>14.51 \mathrm{~m}^{3} /\right.$ day). That is, the irrigation for the recovered vegetation strongly affected the groundwater recharge.

\subsubsection{Impacts on surface water and groundwater exchange}

There was frequent surface water-groundwater exchange in the study region, which dominated the regional hydrological processes. Figure 15 shows the spatial distribution of the multi-year mean daily exchange between surface water and groundwater in the revegetation-absent scenario (Fig. 15a) versus the revegetation-present scenario (Fig. 15b). Specifically, river reach I was in the upper study region, where groundwater was significantly recharged by surface water. River reach II was situated in the lower study region, where significant amounts of groundwater were discharged to the river. In river reach III, both surface water recharge to groundwater and groundwater discharge to surface water were present. River reach III was situated in the irrigated area of Delingha, where it was greatly affected by agricultural, forestland, and grassland irrigation, which led to a relatively complex pattern of surface watergroundwater exchange. The area where river reach III was situated was also the main revegetation area of the study region. Comparisons of Fig. 15a versus Fig. 15b revealed that the direction of surface watergroundwater exchange was reversed in six grid cells, which was attributed to the changes in the irrigation volume within these grid cells after revegetation.

March, July, October, and January were selected as representative months for spring, summer, autumn, and winter, respectively. Figure 16 presents the monthly spatial distribution of the surface watergroundwater exchange in the revegetation-absent scenario versus revegetation-present scenario. Among all seasons, groundwater recharge was the highest in summer and the lowest in winter, while groundwater discharge was the highest in winter and the lowest in summer. Revegetation-induced changes in the seasonal direction of the surface water-groundwater exchange mainly occurred within the irrigated area of Delingha, where river reach III was situated. In addition, revegetation and the related irrigation had a larger impact on the amount of groundwater discharge than on the amount of groundwater recharge. 
Revegetation projects have been conducted in both the Gahai Lake-irrigated area and the irrigated area of Delingha (Fig. 6), but the revegetation only had a relatively high impact on the direction and amount of surface water-groundwater exchange in the latter area; in the former area, there was an almost negligible impact. This discrepancy was attributed to the fact that revegetation in the Gahai Lake-irrigated area was

mainly characterised by conversion of farmland to forestland, and the irrigation volume did not differ significantly between the two land cover types. In contrast, the irrigated area of Delingha was dominated by the conversion of low-coverage grassland to bare land and forestland, and the former two land cover types required no irrigation, while the latter land cover type required a large irrigation volume.

\section{Conclusions}

This study was carried out in the middle and lower reaches of the Bayin River basin in the north-eastern part of the Qaidam Basin, where there is frequent surface water-groundwater interaction and evident vegetation change. A LU-SWAT-MODFLOW model was developed by integrating a coupled SWATMODFLOW model with dynamic HRUs in view of their ability to reflect the actual land cover changes in the basin. The impacts of revegetation and related irrigation on the main hydrological processes in the basin were more accurately simulated and analysed by the LU-SWAT-MODFLOW model than by the original SWAT-MODFLOW model.

The LU-SWAT-MODFLOW model generated dynamic HRUs by pre-defining spatial units where land use/cover changes occurred during the simulated period, thereby overcoming the inability of the original SWAT model to effectively reflect the complete or partial land cover type conversion within the same HRU. This new model outperformed the original SWAT-MODFLOW model in simulating LAI. The LAl is an important parameter of SWAT, as it affects a series of processes such as ET and infiltration; therefore, accurate simulations of LAl are key to accurate hydrological simulations. Moreover, the LU-SWATMODFLOW model outperformed the original SWAT-MODFLOW model in simulating the ET and groundwater table depth of the basin.

The LU-SWAT-MODFLOW model was run in two different scenarios, one with revegetation and the other without to assess the impacts of revegetation and related irrigation on the main hydrological processes in the study region. The results showed that after regional revegetation, ET in the different sub-basins increased by about $1.5 \mathrm{~mm}$ per month and by $6 \mathrm{~mm}$ per year. After revegetation, the groundwater recharge increased by about $1.27 \mathrm{~mm}$ on average per month and $14.02 \mathrm{~mm}$ on average per year. Irrigation for the recovered vegetation strongly affected the groundwater recharge. Meanwhile, the direction and amount of surface water-groundwater exchange underwent evident changes in areas where revegetation was characterised by the conversion of low-coverage grassland and bare land to forestland. In areas where revegetation was characterised by the conversion of farmland to forestland, the irrigation volume was not greatly altered, and thus, this transition had a weak impact on the direction and amount of surface water-groundwater exchange. Changes in the direction and amount of surface watergroundwater exchange may lead to a series of ecological and environmental issues. To avoid problems in the future, water-saving irrigation techniques should be advocated when conducting revegetation in arid 
inland river basins. In addition, our findings indicate that it would be advantageous to preferentially apply revegetation measures that promote the conversion of farmland to forestland/grassland, provided that they do not adversely affect regional economic development.

\section{Declarations}

Funding: This research was funded by the National Natural Science Foundation of China (No. 41801094) and grants from the Natural Science Foundation of Qinghai Province, China (No. 2021-ZJ-705).

Conflicts of interest: The authors declare that there are no conflicts of interest.

Availability of data and material: The datasets used or analysed during the current study are available from the corresponding author on reasonable request.

Code availability: Not applicable

\section{References}

Abella SR, Chiquoine LP, Newton AC, Vanier CH (2015) Restoring a desert ecosystem using soil salvage, revegetation, and irrigation. J Arid Environ 115:44-52. doi: 10.1016/j.jaridenv.2015.01.003

Alemayehu T, Griensven Av, Bauwens W (2016) Evaluating CFSR and Watch data as input to SWAT for the estimation of the potential evapotranspiration in a data-scarce Eastern-African Catchment. J Hydrol Eng 21:12-18. doi: 10.1061/(ASCE)HE.1943-5584.0001305

Bailey RT, Wible TC, Arabi M et al. (2016) Assessing regional-scale spatio-temporal patterns of groundwater-surface water interactions using a coupled SWAT-MODFLOW model. Hydrol Process 30:4420-4433. doi: 10.1002/hyp.10933

N. Moriasi, J. G. Arnold, M. W. Van Liew et al. (2007) Model evaluation guidelines for systematic quantification of accuracy in watershed simulations. Trans ASABE 50:885-900. doi: $10.13031 / 2013.23153$

Dahlstrom DJ (2015) Calibration and uncertainty analysis for complex environmental models. Groundwater 53:673-674. doi: 10.1111/gwat.12360

Feng XM, Fu BJ, Piao SL et al. (2016) Revegetation in China's Loess Plateau is approaching sustainable water resource limits. Nat Clim Change 6:1019-1022. doi: 10.1038/nclimate3092

Immerzeel WW, Droogers P (2008) Calibration of a distributed hydrological model based on satellite evapotranspiration. J Hydrol 349:411-424. doi: 10.1016/j.jhydrol.2007.11.017

G. Arnold, D. N. Moriasi, P. W. Gassman et al. (2012) SWAT: Model use, calibration, and validation. Trans ASABE 55:1491-1508. doi: 10.13031/2013.42256 
Jackson RB, Jobbàgy EG, Avissar R et al. (2005) Trading water for carbon with biological carbon sequestration. Science 310:1944-1947-19477. doi: 10.1126/science.1119282

Jin X, He CS, Zhang LH, Zhang BQ (2018) A modified groundwater module in SWAT for improved streamflow simulation in a large, arid endorheic river watershed in Northwest China, Chin. Chin Geogr Sci 28:47-60. doi: 10.1007/s11769-018-0931-0

Jin X, Jin YX (2020) Calibration of a distributed hydrological model in a data-scarce basin based on GLEAM datasets. Water 12:897-910. doi: 10.3390/w12030897

Jin X, Zhang L, Gu J et al. (2015) Modelling the impacts of spatial heterogeneity in soil hydraulic properties on hydrological process in the upper reach of the Heihe River in the Qilian Mountains, Northwest China. Hydrol Process 29:3318-3327. doi: 10.1002/hyp.10437

Kim NW, Chung IM, Won YS, Arnold JG (2008) Development and application of the integrated SWATMODFLOW model. J Hydrol 356:1-16. doi: 10.1016/j.jhydrol.2008.02.024

Liu W, Park S, Bailey RT et al. (2019) Comparing SWAT with SWAT-MODFLOW hydrological simulations when assessing the impacts of groundwater abstractions for irrigation and drinking water. Hydrol Earth Syst Sci:1-51. doi: 10.5194/hess-2019-232

Ma N, Szilagyi J, Zhang Y, Liu W (2019) Complementary-relationship-based modeling of terrestrial evapotranspiration across China during 1982-2012: Validations and spatiotemporal analyses. J Geophys Res Atmos 124:4326-4351. doi: 10.1029/2018JD029850

Ma TX, Duan Z, Li R, Song X (2019) Enhancing SWAT with remotely sensed LAl for improved modelling of ecohydrological process in subtropics. J Hydrol 570:802-815. doi: 10.1016/j.jhydrol.2019.01.024

Menz MHM, Dixon KW, Hobbs RJ (2013) Ecology. Hurdles and opportunities for landscape-scale restoration. Science 339:526-527. doi: 10.1126/science.1228334

Minacapilli M, lovino M, D'Urso G (2008) A distributed agro-hydrological model for irrigation water demand assessment. Agric Water Manag 95:123-132. doi: 10.1016/j.agwat.2007.09.008

Nyeko M (2015) Hydrologic modelling of data scarce basin with SWAT model: Capabilities and limitations. Water Resour Manag 29:81-94. doi: 10.1007/s11269-014-0828-3

Padgett PE, Kee SN, Allen EB (2000) The effects of irrigation on revegetation of semi-arid coastal sage scrub in southern California. Environ Manag 26:427-435. doi: 10.1007/s002670010100

Panagopoulos Y, Makropoulos C, Baltas E, Mimikou M (2011) SWAT parameterization for the identification of critical diffuse pollution source areas under data limitations. Ecol Modell 222:35003512. doi: 10.1016/j.ecolmodel.2011.08.008 
Quinn P, Beven K, Chevallier P, Planchon $O$ (1991) The prediction of hillslope flow paths for distributed hydrological modelling using digital terrain models. Hydrol Process 5:59-79. doi:

10.1002/hyp.3360050106

Reshmidevi TV, Nagesh Kumar D (2014) Modelling the impact of extensive irrigation on the groundwater resources. Hydrol Process 28:628-639. doi: 10.1002/hyp.9615

Reynolds JF, Smith DMS, Lambin EF et al. (2007) Global desertification: Building a science for dryland development. Science 316:847-851. doi: 10.1126/science.1131634

Shen Q, Gao GY, Fu BJ, Lü YH (2015) Sap flow and water use sources of shelter-belt trees in an arid inland river basin of Northwest China. Ecohydrology 8:1446-1458. doi: 10.1002/eco.1593

Sun X, Bernard-Jannin L, Garneau C et al. (2016) Improved simulation of river water and groundwater exchange in an alluvial plain using the SWAT model. Hydrol Process 30:187-202. doi:

10.1002/hyp. 10575

Wang QR, Liu R, Men C et al. (2018) Effects of dynamic land use inputs on improvement of SWAT model performance and uncertainty analysis of outputs. J Hydrol 563:874-886. doi:

10.1016/j.jhydrol.2018.06.063

White KL, Chaubey I (2005) Sensitivity analysis, calibration, and validations for a multisite and multivariable SWAT model. J Am Water Resources Assoc 41:1077-1089. doi: 10.1111/j.17521688.2005.tb03786.x

Xu X, Jiang Y, Liu M et al. (2019) Modeling and assessing agro-hydrological processes and irrigation water saving in the middle Heihe River basin. Agric Water Manag 211:152-164. doi:

10.1016/j.agwat.2018.09.033

Yang Q, Zhang X (2016) Improving SWAT for simulating water and carbon fluxes of forest ecosystems.

Sci Total Environ 569-570:1478-1488. doi: 10.1016/j.scitotenv.2016.06.238

Zhang C, Shoemaker CA, Woodbury JD et al. (2013) Impact of human activities on stream flow in the Biliu River basin, China. Hydrol Process 27:2509-2523. doi: 10.1002/hyp.9389

\section{Figures}




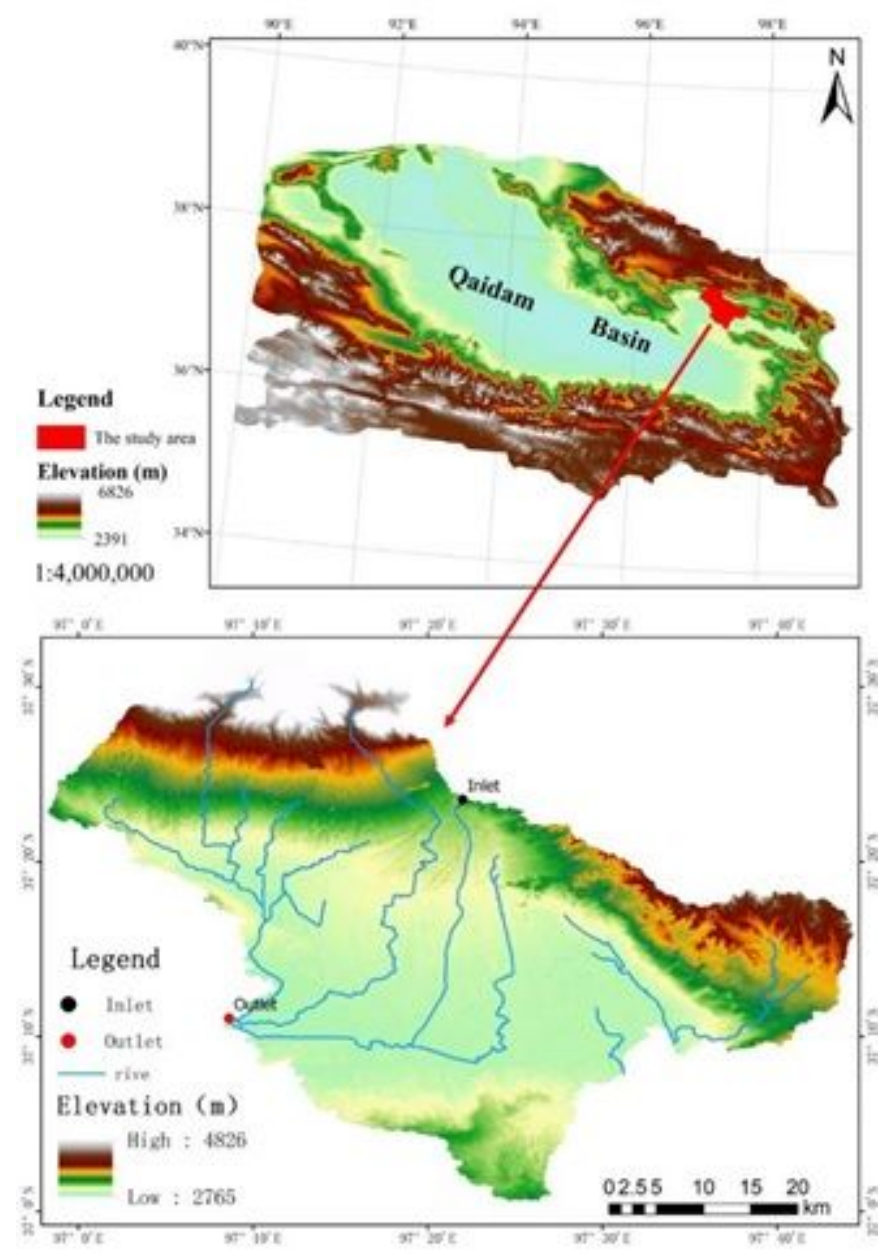

\section{Figure 1}

Study area. Note: The designations employed and the presentation of the material on this map do not imply the expression of any opinion whatsoever on the part of Research Square concerning the legal status of any country, territory, city or area or of its authorities, or concerning the delimitation of its frontiers or boundaries. This map has been provided by the authors.

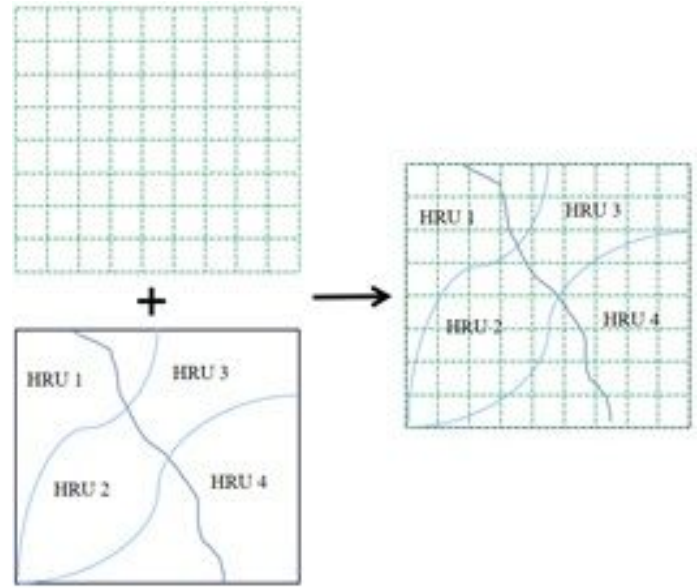

Figure 2

Integration of SWAT and MODFLOW computing units. 


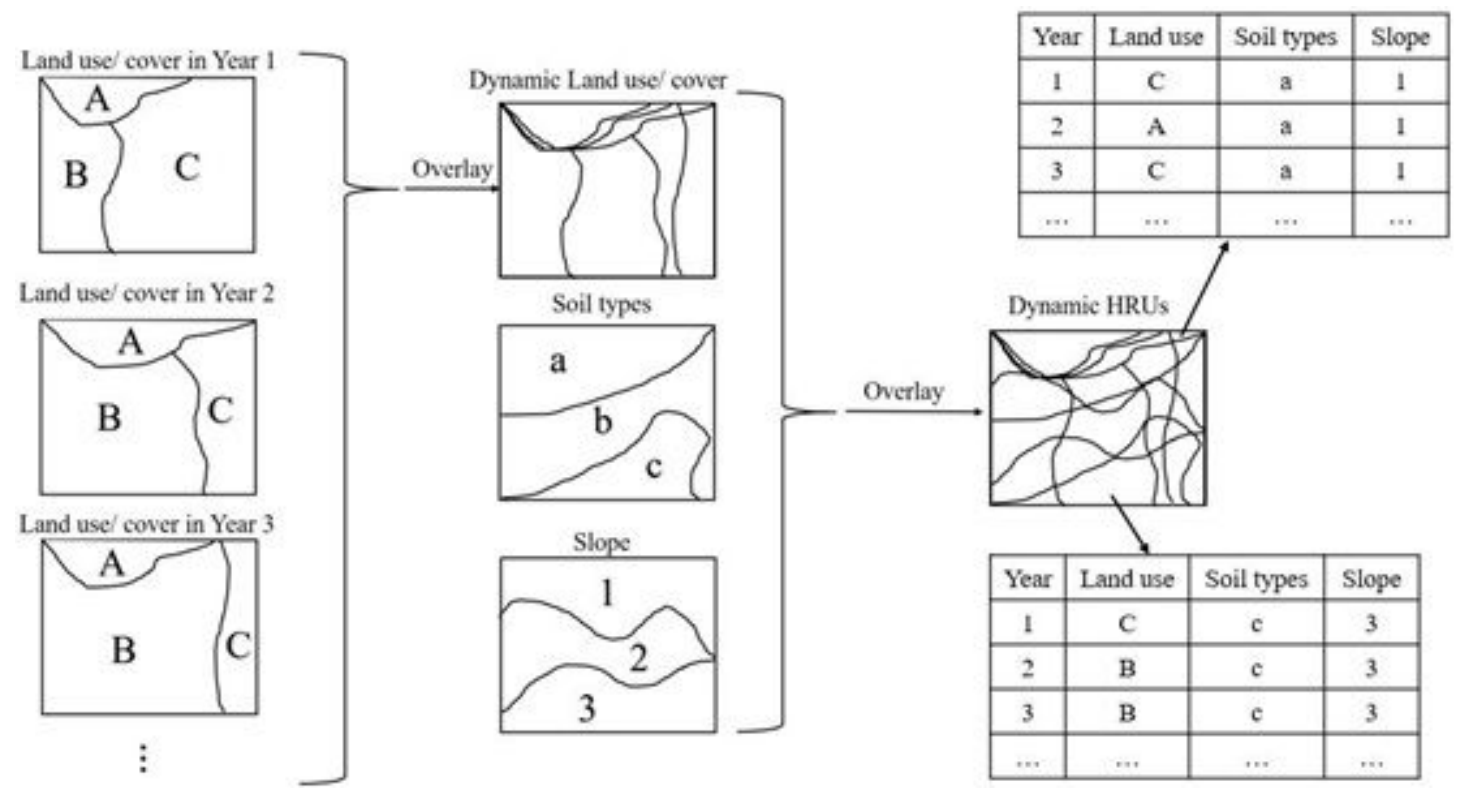

Figure 3

Production of dynamic hydrological response units (HRUs).

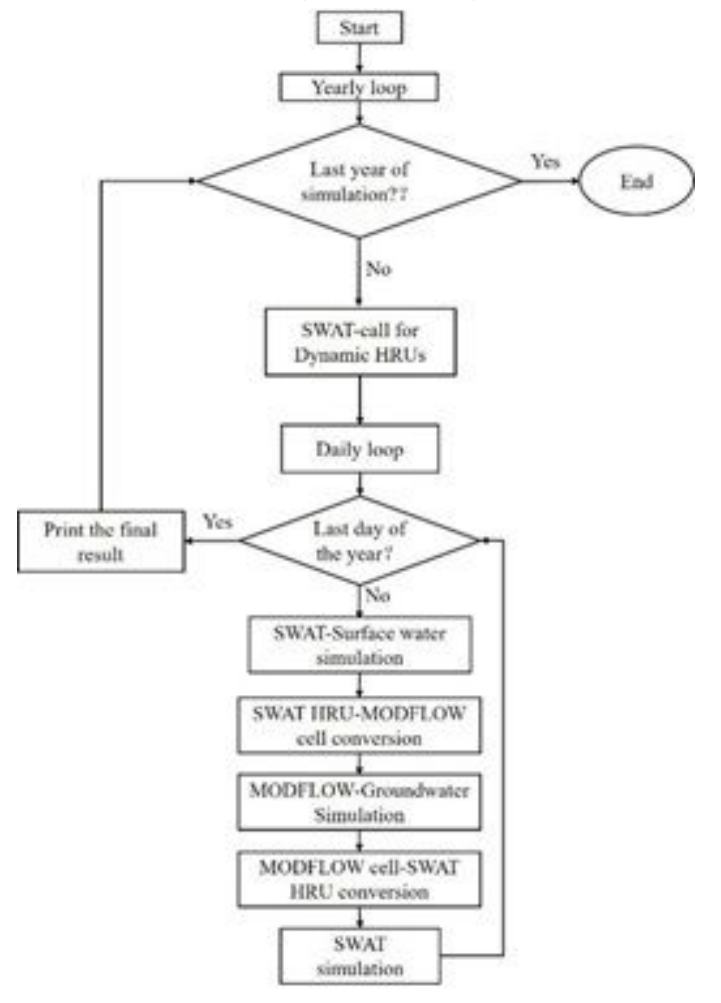

Figure 4

Flowchart of the SWAT-MODFLOW coupled model based on dynamic hydrological response units (HRUs). 

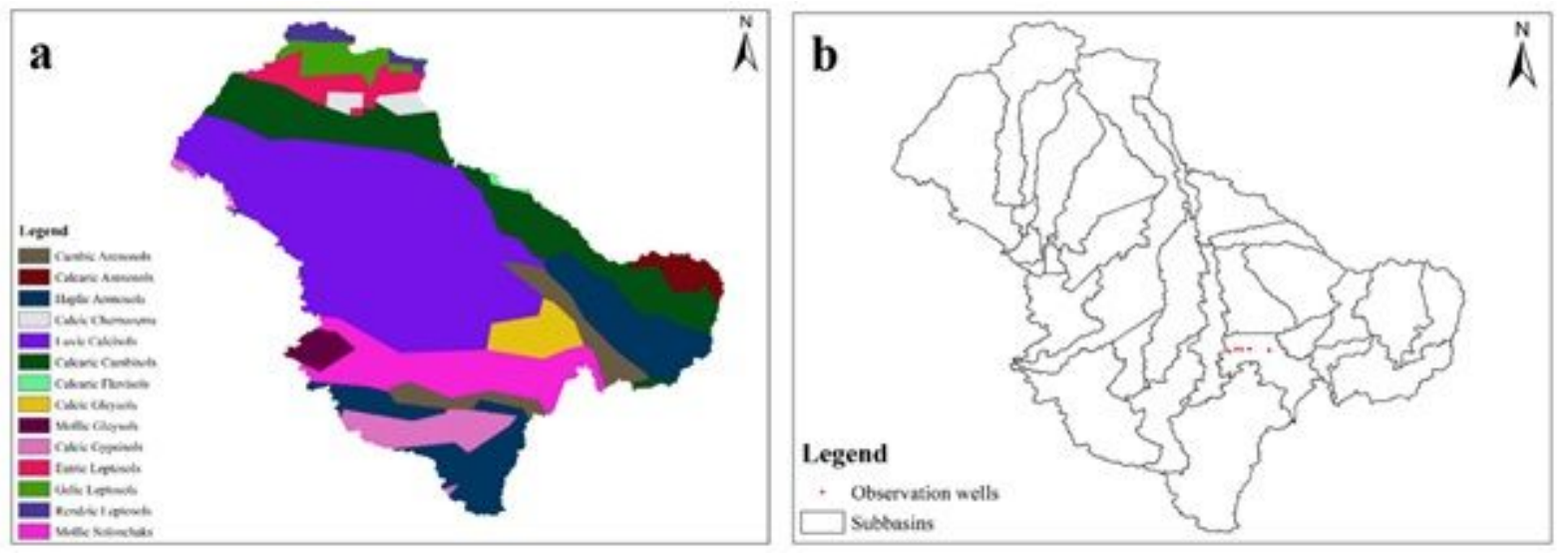

Figure 5

Soil types (a) and Sub-basins (b) input to the SWAT model. Note: The designations employed and the presentation of the material on this map do not imply the expression of any opinion whatsoever on the part of Research Square concerning the legal status of any country, territory, city or area or of its authorities, or concerning the delimitation of its frontiers or boundaries. This map has been provided by the authors.
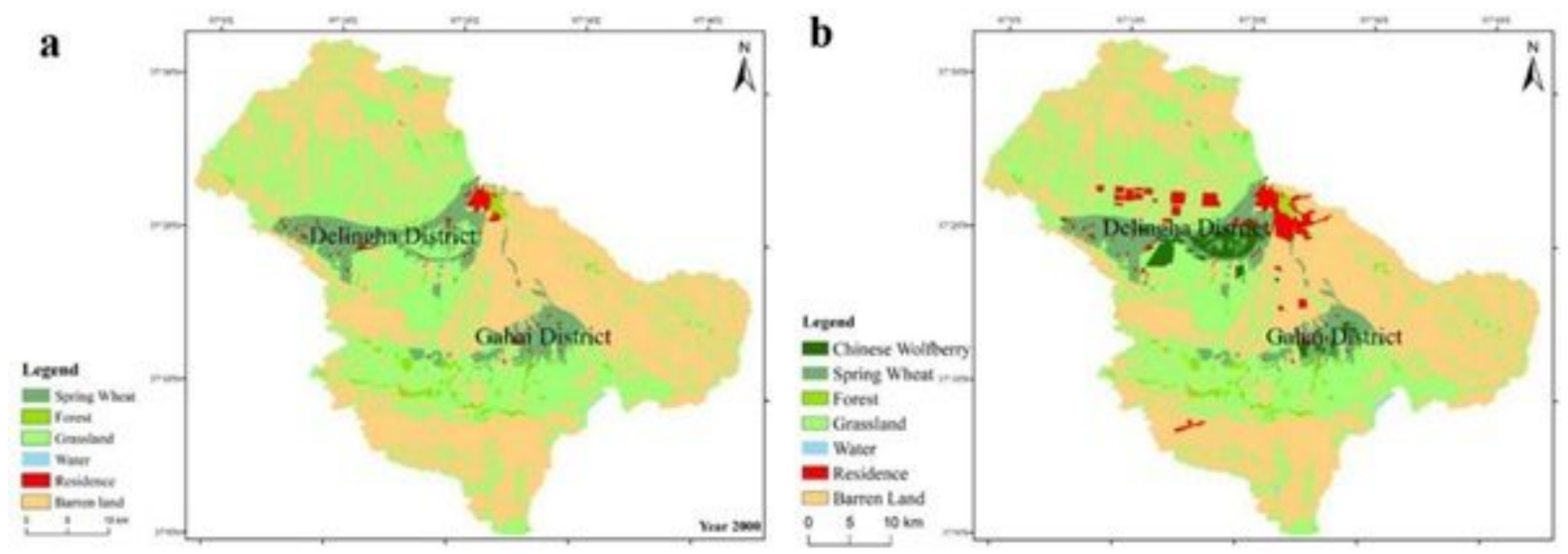

\section{Figure 6}

Revegetation status of the study region in 2000 (a) and 2018 (b). Note: The designations employed and the presentation of the material on this map do not imply the expression of any opinion whatsoever on the part of Research Square concerning the legal status of any country, territory, city or area or of its authorities, or concerning the delimitation of its frontiers or boundaries. This map has been provided by the authors. 


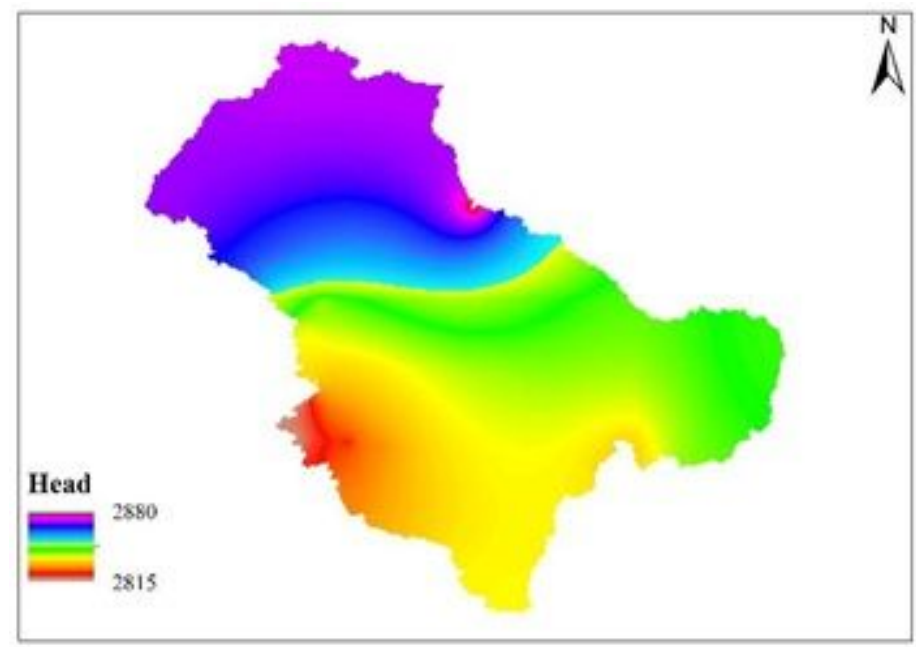

Figure 7

Initial heads Note: The designations employed and the presentation of the material on this map do not imply the expression of any opinion whatsoever on the part of Research Square concerning the legal status of any country, territory, city or area or of its authorities, or concerning the delimitation of its frontiers or boundaries. This map has been provided by the authors.

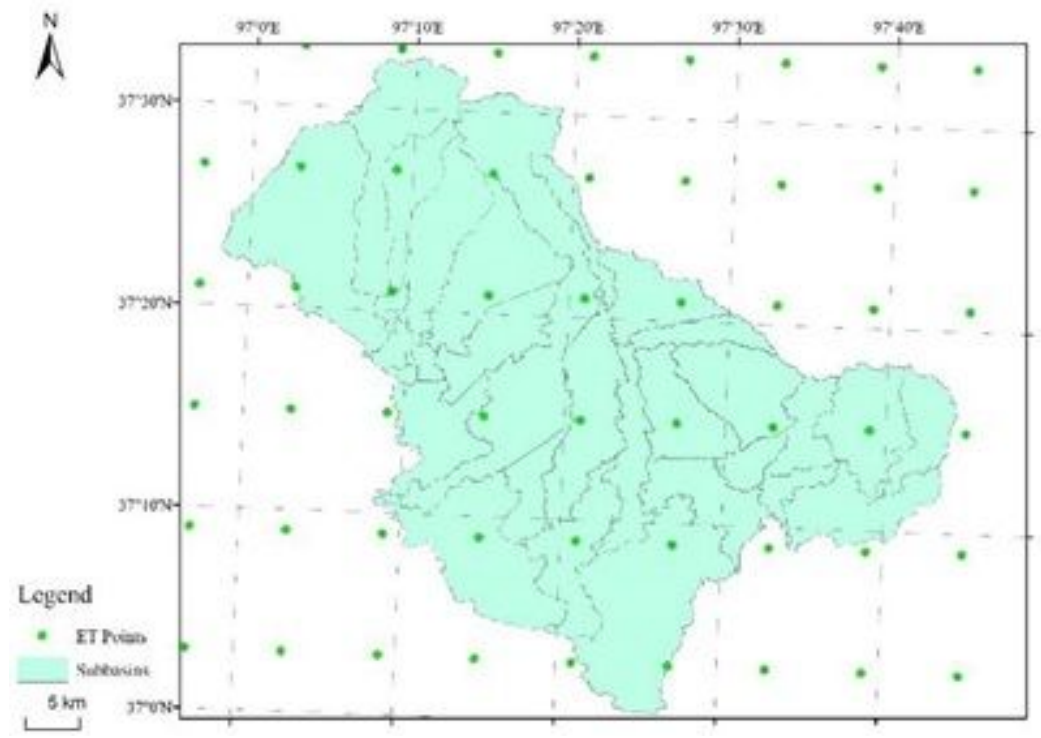

Figure 8

Locations of ET data points Note: The designations employed and the presentation of the material on this map do not imply the expression of any opinion whatsoever on the part of Research Square concerning the legal status of any country, territory, city or area or of its authorities, or concerning the delimitation of its frontiers or boundaries. This map has been provided by the authors. 


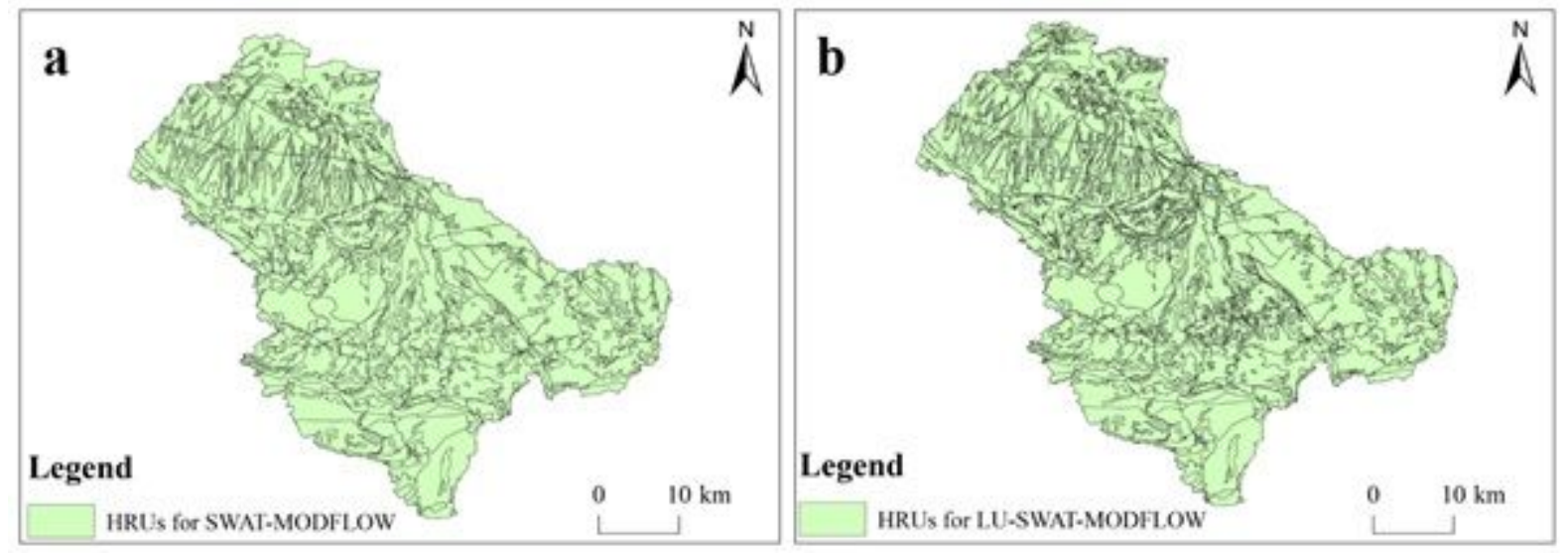

Figure 9

HRUs generated by SWAT-MODFLOW (a) and LU-SWAT-MODFLOW (b) Note: The designations employed and the presentation of the material on this map do not imply the expression of any opinion whatsoever on the part of Research Square concerning the legal status of any country, territory, city or area or of its authorities, or concerning the delimitation of its frontiers or boundaries. This map has been provided by the authors. 

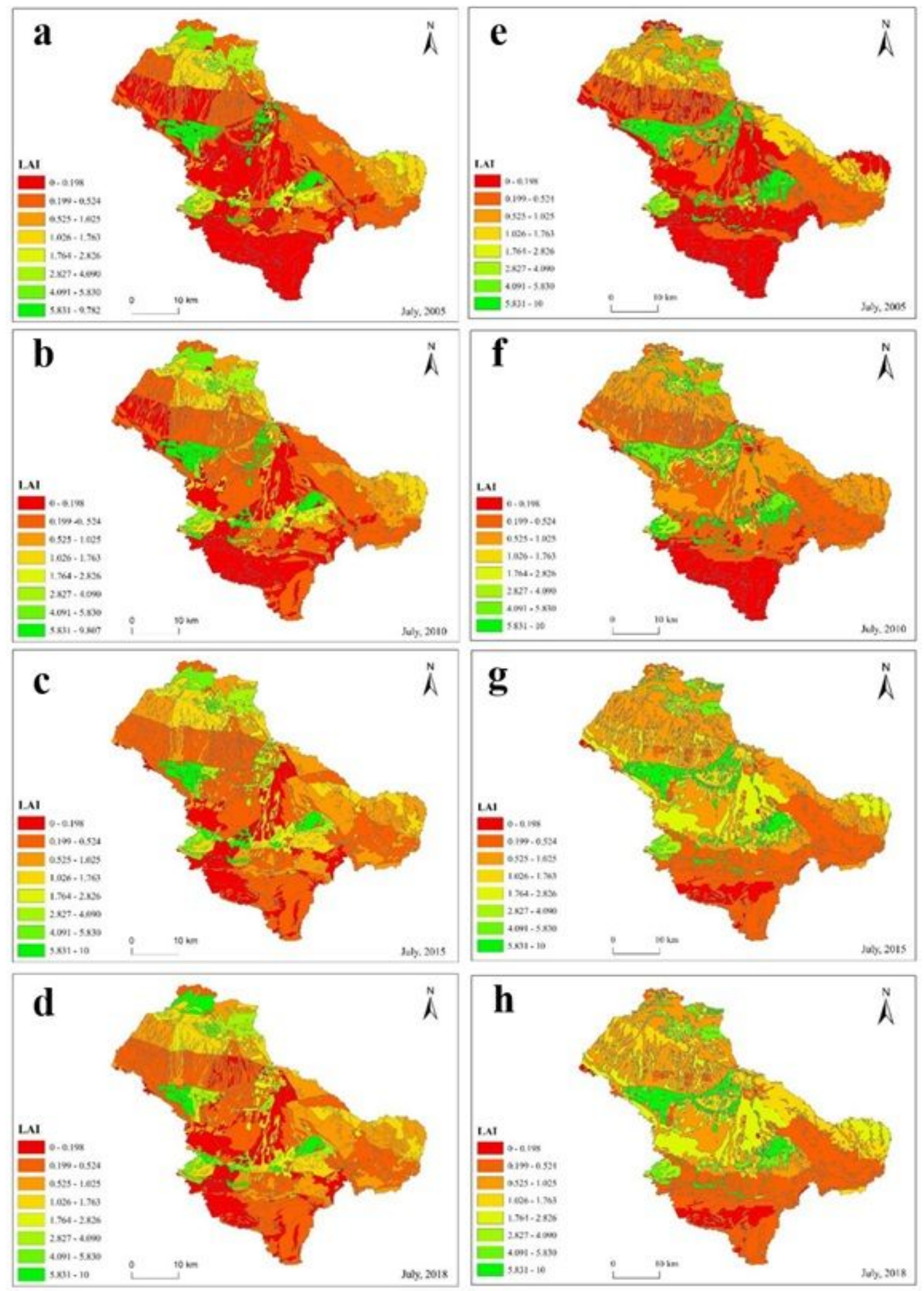

Figure 10

Simulated leaf area index (LAI) from the calibrated original SWAT-MODFLOW model (a-d) versus the calibrated LU-SWAT-MODFLOW model (e-h). Note: The designations employed and the presentation of the material on this map do not imply the expression of any opinion whatsoever on the part of Research Square concerning the legal status of any country, territory, city or area or of its authorities, or concerning the delimitation of its frontiers or boundaries. This map has been provided by the authors. 

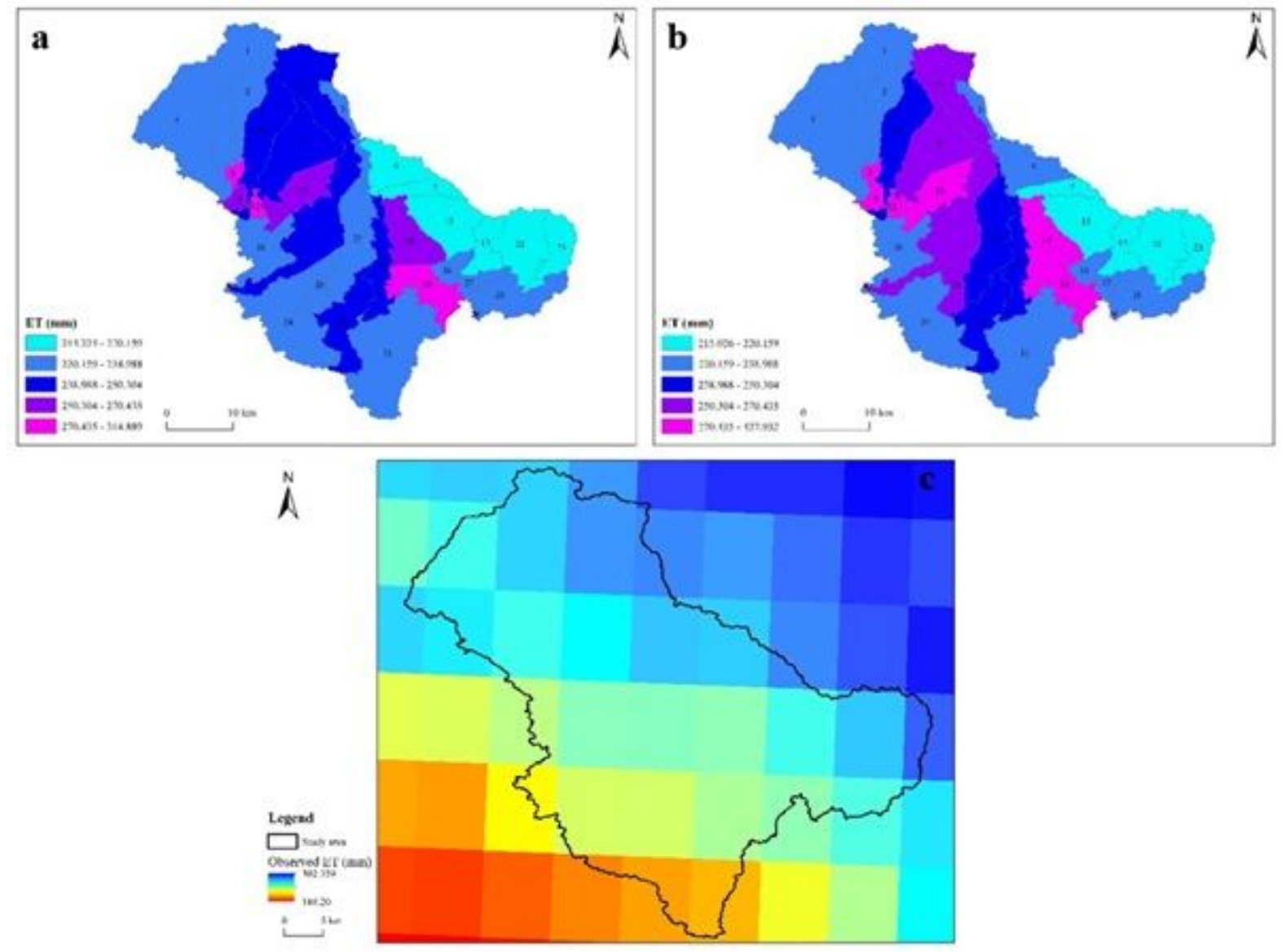

\section{Figure 11}

Multi-year mean ET simulated by SWAT-MODFLOW (a), LU-SWAT-MODFLOW (b) and retrieved from remote sensing images (c) Note: The designations employed and the presentation of the material on this map do not imply the expression of any opinion whatsoever on the part of Research Square concerning the legal status of any country, territory, city or area or of its authorities, or concerning the delimitation of its frontiers or boundaries. This map has been provided by the authors. 

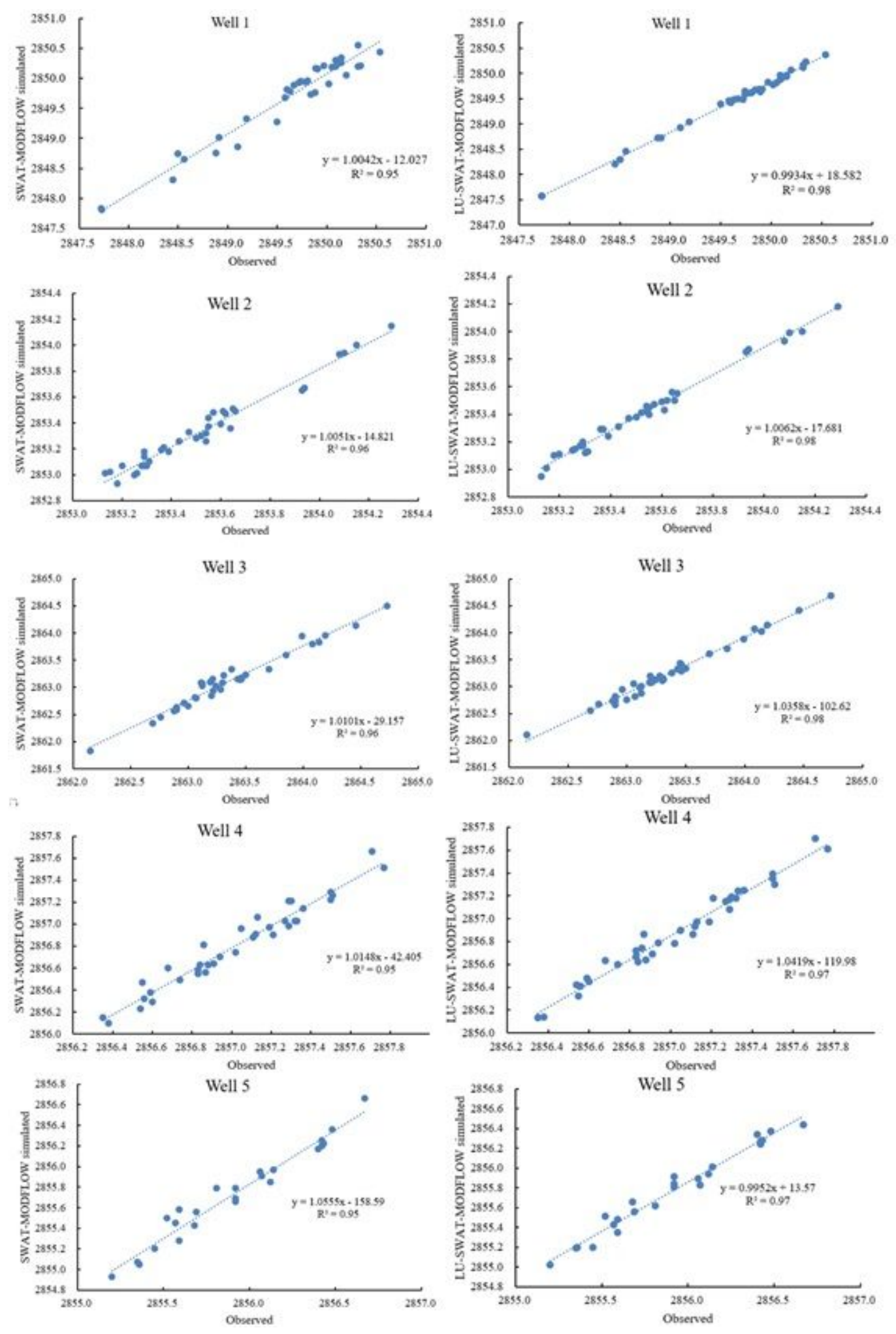

Figure 12

Monthly groundwater table depth simulated by the SWAT-MODFLOW model versus the LU-SWATMODFLOW model. 

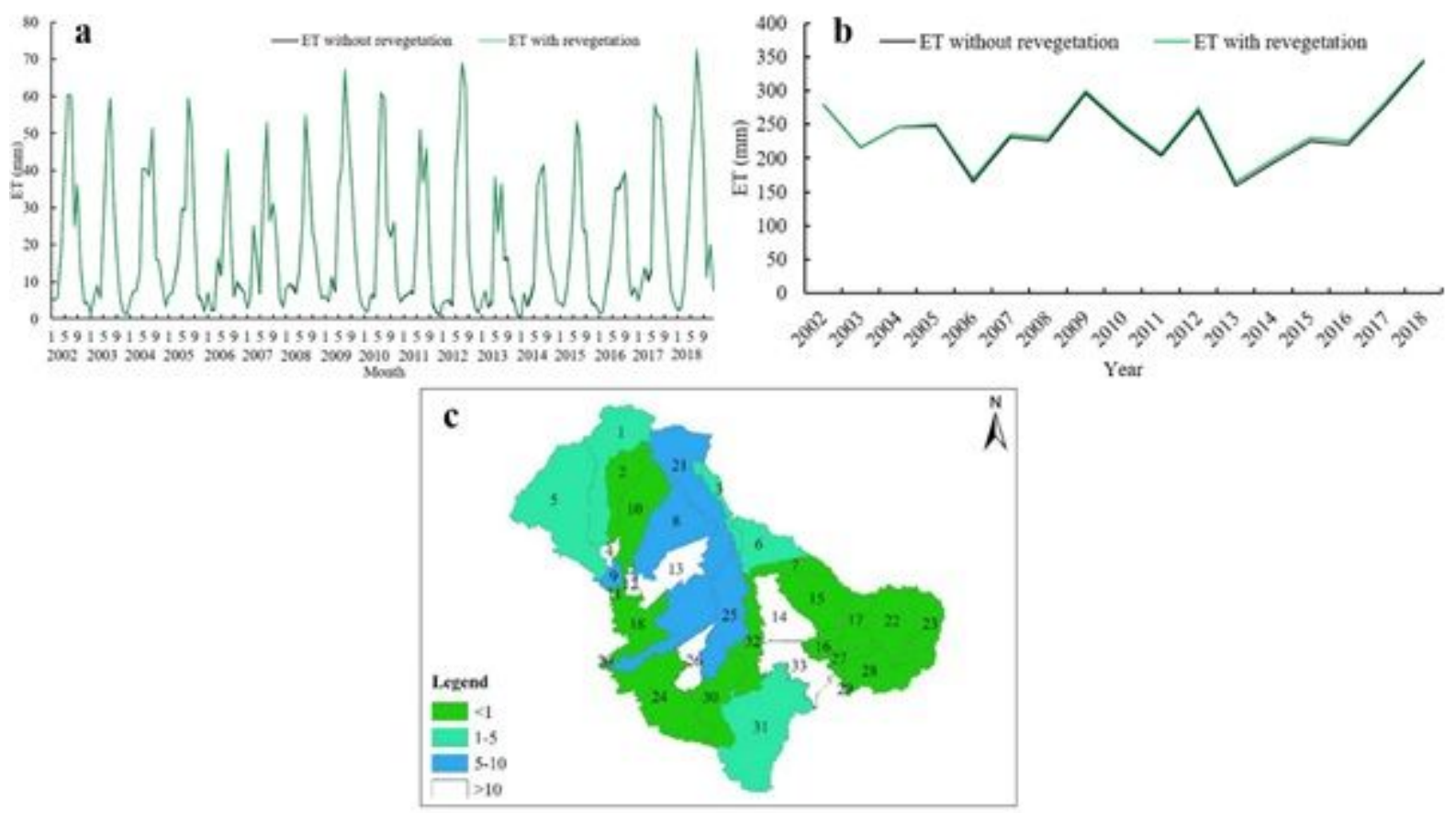

\section{Figure 13}

Monthly (a) and yearly (b) ET with revegetation and without revegetation; Yearly average ET change in different sub-basins after revegetation (c) Note: The designations employed and the presentation of the material on this map do not imply the expression of any opinion whatsoever on the part of Research Square concerning the legal status of any country, territory, city or area or of its authorities, or concerning the delimitation of its frontiers or boundaries. This map has been provided by the authors.
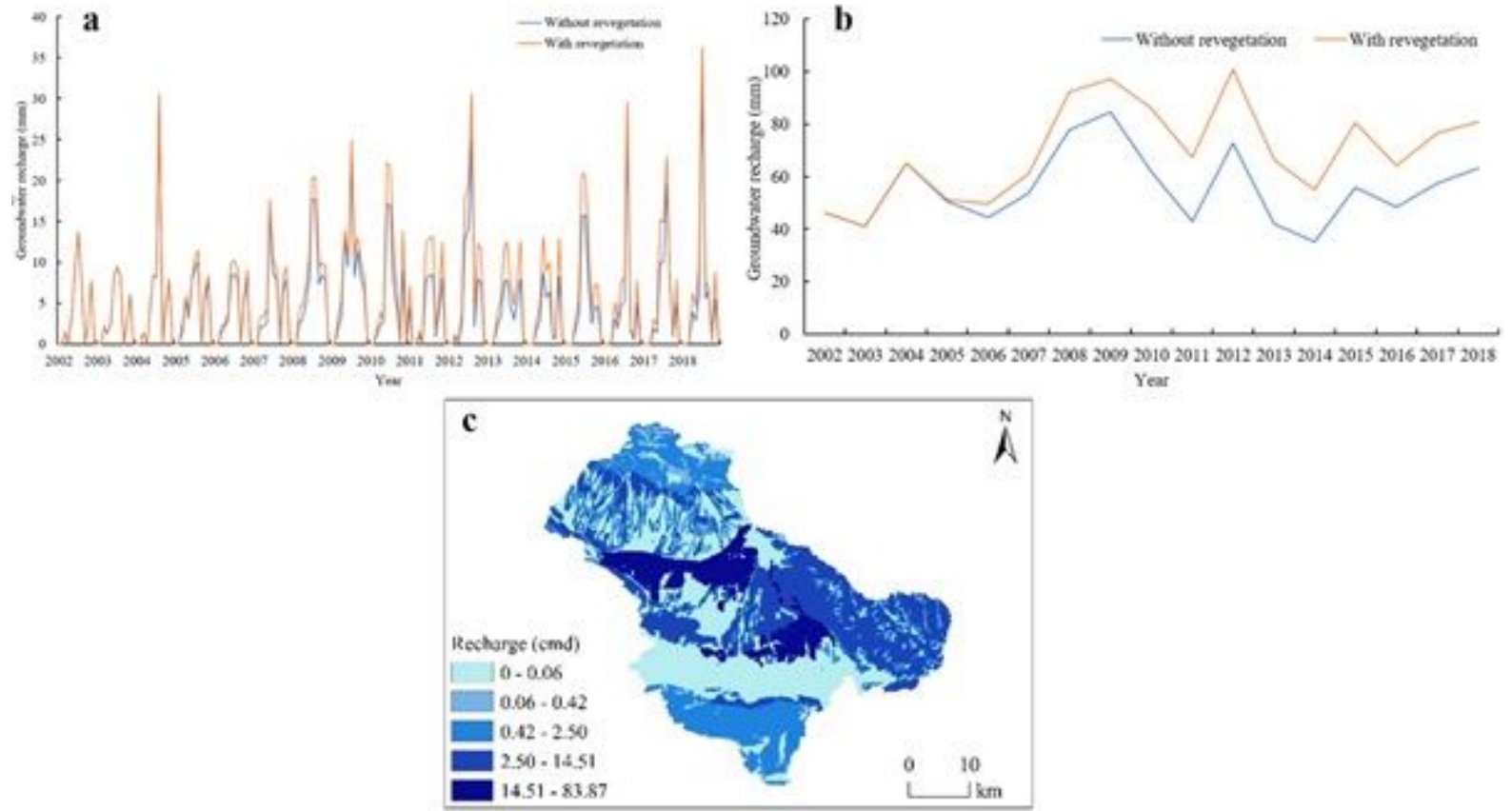

Figure 14 
Monthly (a) and yearly (b) groundwater recharge with and without revegetation; Yearly average groundwater recharge after revegetation in space (c). Note: The designations employed and the presentation of the material on this map do not imply the expression of any opinion whatsoever on the part of Research Square concerning the legal status of any country, territory, city or area or of its authorities, or concerning the delimitation of its frontiers or boundaries. This map has been provided by the authors.

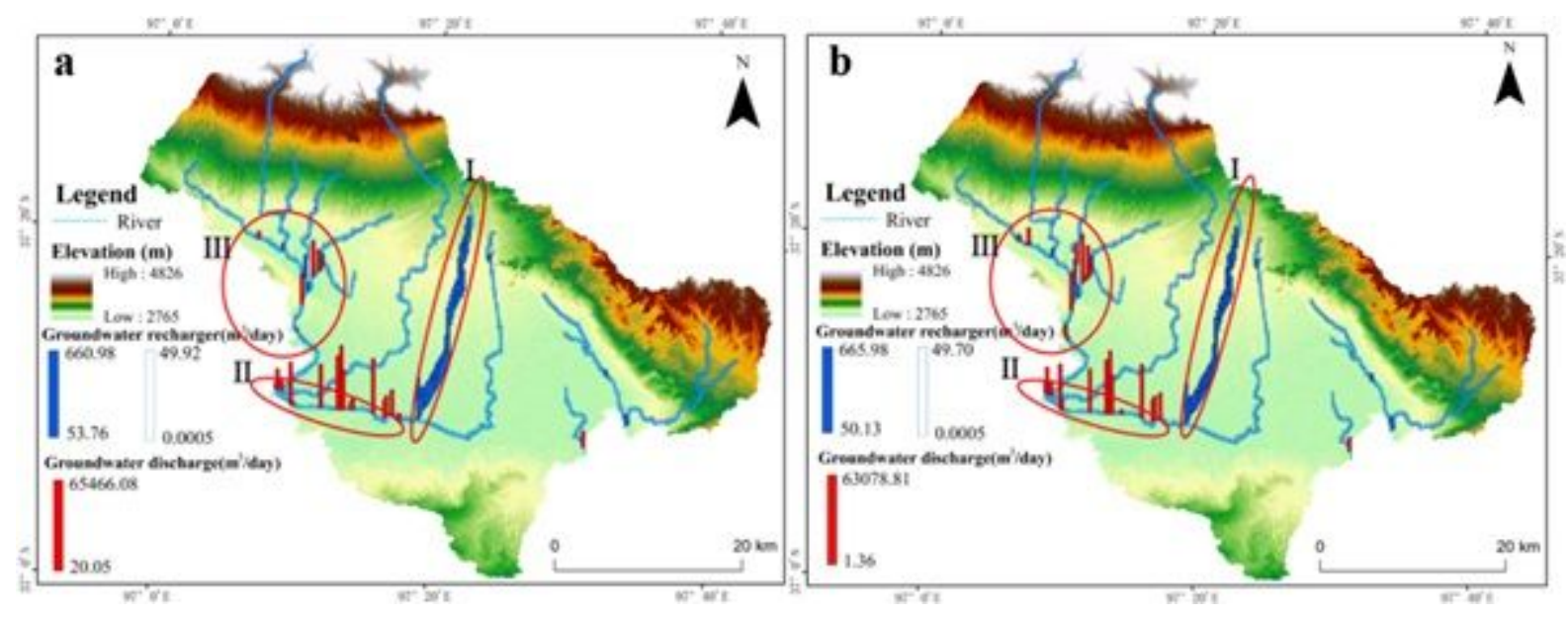

\section{Figure 15}

Multi-year mean daily exchange without (a) and with (b) revegetation between surface water and groundwater simulated by the LU-SWAT-MODFLOW model. Note: The designations employed and the presentation of the material on this map do not imply the expression of any opinion whatsoever on the part of Research Square concerning the legal status of any country, territory, city or area or of its authorities, or concerning the delimitation of its frontiers or boundaries. This map has been provided by the authors. 

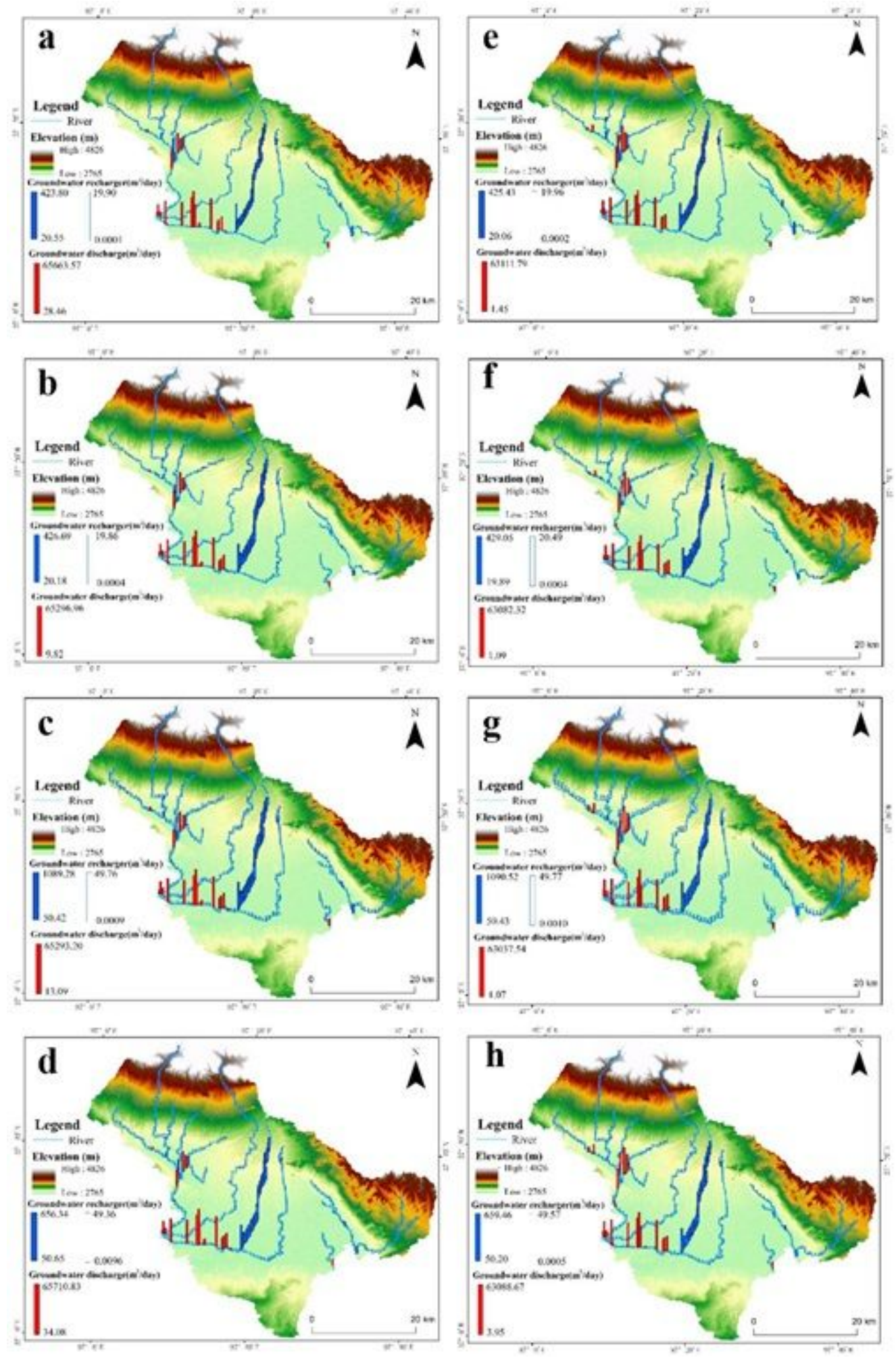

Figure 16

LU-SWAT-MODFLOW simulated surface water and groundwater exchange without (a-d) and with (e-h) revegetation in different seasons. Note: The designations employed and the presentation of the material on this map do not imply the expression of any opinion whatsoever on the part of Research Square concerning the legal status of any country, territory, city or area or of its authorities, or concerning the delimitation of its frontiers or boundaries. This map has been provided by the authors. 